\title{
"Onde as forças vivas do trabalho se ajuntam em desmedida": dinâmicas da reprodução do capital em São Paulo durante a epidemia de febre amarela
}

Monique Felix Borin*

\section{RESUMO}

O presente artigo aborda as dinâmicas de reprodução de capital nos investimentos no mercado de aluguéis de moradias coletivas na Santa Ifigênia, bairro central de São Paulo, durante a epidemia de febre amarela que atingiu algumas regiôes do Brasil nas décadas finais do século XIX. Nos centramos principalmente na atuação de Carlo Gilardi, investidor urbano do mercado de aluguéis, imigrante proveniente da região de Piemonte, Itália, para explorar as relaçóes entre a colonialidade, as epidemias e as estratégias de controle urbano da população urbana despossuída. Os discursos sobre as aglomeraçóes urbanas são analisados a partir do cruzamento de fontes primárias, especialmente o relatório de inspeção dos cortiços elaborado por uma comissão designada pelo poder público em 1893, pedidos da Série Obras Particulares e registros de transações fundiárias.

Palavras-chave: febre amarela; urbanização; colonialidade; cortiços; imigração.

\section{"Where the living forces of work gather in excess": dynamics of capital reproduction in Sáo Paulo during the yellow fever epidemic}

\begin{abstract}
This paper discusses the dynamics of capital reproduction in collective housing rental market investments in Santa Ifigênia, a neighborhood in central São Paulo, during the yellow fever epidemic that hit some regions of Brazil in the late 19th century. Through the actions of Carlo Gilardi, an immigrant from Italy's Piedmont region who became an
\end{abstract}

DOI: http://dx.doi.org/10.1590/2237-101X02204807

Artigo recebido em 2 de fevereiro de 2021 e aceito para publicação em 7 de junho de 2021.

* Pesquisadora do Centro Interdisciplinar de Estudos sobre Cidade, Campinas/SP - Brasil. E-mail: moniquebfelix@gmail.com. ORCID: https://orcid.org/0000-0002-8374-937X.

Este artigo é resultado de pesquisa financiada pela Fundação de Amparo à Pesquisa do Estado de São Paulo (FAPESP), Processo nº 15/14115-0. 
“ONDE AS FORÇAS VIVAS DO TRABALHO SE AJUNTAM EM DESMEDIDA": DINÂMICAS DA REPRODUÇÃO DO CAPITAL EM Sáo Paulo durante a ePidemia de FEBre amarela

Monique Felix Borin

urban investor in São Paulo's rental market, the article explores the relationships between coloniality, epidemics, and strategies for controlling the urban working class. The article analyzes discourses about collective housing using primary sources such as an 1893 tenement inspection report made by a government-appointed commission, Private Works Series orders, and land transaction records.

Keywords: yellow fever; urbanization; coloniality; tenements; immigration.

"Donde las fuerzas vivas del trabajo se juntan en desmedida": dinámicas de la reproducción del capital en São Paulo durante la pandemia de fiebre amarilla

\section{RESUMEN}

El presente artículo aborda las dinámicas de reproducción de capital en las inversiones en el mercado de alquileres de residencias colectivas en Santa Ifigênia, barrio central de São Paulo, durante la pandemia de la fiebre amarilla que afectó algunas regiones de Brasil en las décadas finales del siglo XIX. Nos centramos principalmente en la actuación de Carlo Gilardi, inversor urbano del mercado de alquileres, inmigrante proveniente de la región Piemonte, Italia, para explorar las relaciones entre la colonialidad, las pandemias y las estrategias de control urbano de la población urbana desposeída. Los discursos sobre las aglomeraciones urbanas son analizados a partir del cruzamiento de fuentes primarias, especialmente el informe de inspección de los cortiços elaborado por una comisión designada por el poder público en 1893, pedidos de la Serie de Obras Particulares y registros de transacciones de tierras.

Palabras Clave: fiebre amarilla; urbanización; colonialidad; viviendas; inmigración.

As epidemias de febre amarela marcam o imaginário do século XIX no Brasil: tanto cidades litorâneas como a capital federal de então, Rio de Janeiro, quanto importantes centros econômicos no interior do país, como Campinas (SP), se viram duramente afetados por surtos da doença. Os impactos das epidemias sobre essas cidades foram esmiuçadamente estudados, no caso da capital federal com especial relevo para as disputas em torno da vacinação compulsória e das reformas urbanas subjacentes (BENCHIMOL, 1992). No caso de Campinas, as análises se debruçaram principalmente no impacto da epidemia para a despromoçáo da cidade no cenário político-econômico, salientando o expressivo decréscimo populacional tanto pela mortalidade elevada, como pela fuga da cidade por medo do contágio (MARTINS, 2015). São Paulo não vivenciou nenhum surto tão expressivo de febre amarela, mas foram diversos os impactos da epidemia na cidade. Pensando em termos de legislação sanitária, tais impactos foram mais expressivos que os da própria pandemia de gripe espanhola, que se estendeu de 1918 a 1920, com uma letalidade vertiginosamente superior 
“ONDE AS FORÇAS VIVAS DO TRABALHO SE AJUNTAM EM DESMEDIDA": DINÂMICAS DA REPRODUÇÃO DO CAPITAL EM Sáo Paulo durante a ePidemia de FEBre amarela

Monique Felix Borin

a qualquer ocorrência de outra enfermidade (BERTOLLI FILHO, 2003). O surto de febre amarela enfrentado no ano de 1893 na capital paulista durou cerca de dois meses, e esteve principalmente concentrado em um foco epidêmico: o bairro da Santa Ifigênia, contíguo à centralidade histórica a oeste. ${ }^{1}$

Para entender as causas que levaram a tal foco epidêmico, bem como para prevenir futuros surtos, dois fatores foram especialmente considerados pelo poder público na gestão da epidemia: as dinâmicas demográficas do bairro e as condiçôes de suas moradias. Santa Ifigênia era um dos bairros mais densamente povoados da cidade em fins do século XIX, apesar das suas dimensôes territoriais exíguas. A freguesia como um todo passou de aproximadamente $12 \mathrm{mil}$ habitantes em 1886 a 43 mil habitantes em 1893 - cerca de 12 mil a mais do que a segunda freguesia mais habitada, a do Brás (ANDRADE, 1991, p. 82). Esses dois fatores foram enfatizados como centrais em análises previamente feitas pelo engenheiro Teodoro Sampaio. ${ }^{2}$ Em uma série de ofícios encaminhados ao secretário de negócios do interior, Cesário Motta Júnior, nos meses anteriores à epidemia, Sampaio rogava por intervençôes de cunho sanitário para a prevençâo da disseminação de doenças, especialmente febre amarela e tifo, indicando, inclusive, o bairro de Santa Ifigênia como uma área prioritária para início dessas intervenções, justamente pelas aglomeraçôes em moradias. ${ }^{3}$ Com o desencadeamento da epidemia, Sampaio é autorizado a formar uma equipe para realizar um levantamento detalhado da área mais afetada, com foco determinado pelo próprio engenheiro em estalagens e cortiços do bairro. Assim, formou-se a comissão chefiada por Teodoro Sampaio, composta por mais um engenheiro, Luiz César do Amaral Gama, e três médicos, Candido Espinheira, Gregório da Cunha Vasconcellos e Octávio Marcondes Machado, responsáveis pela produção do "Relatório de exame e inspecção das habitaçóes operárias e cortiços de Sta. Ephigenia", que entregou o documento final em 19 de outubro de 1893 (CORDEIRO, 2010, p. 12).

O "Relatório de exame e inspecção das habitaçóes operárias e cortiços de Sta. Ephigenia" é um documento amplamente estudado pela sua importância na elaboração de políticas sanitárias pelo poder público no final do século XIX. A edição fac-símile do

\footnotetext{
${ }^{1}$ Relatório da Commissão de exame e inspecção das habitaçóes operarias e cortiços no Districto de Sta. Ephigenia - 1893. Edição Fac-símile: CORDEIRO, Simone Lucena (org.). Os cortiços de Santa Ifigênia: sanitarismo e urbanização (1893). São Paulo: Imprensa Oficial; Arquivo Público do Estado de S. Paulo, 2010. ${ }^{2}$ Theodoro Sampaio foi um engenheiro, geógrafo, historiador, político e escritor, nascido em 1855 na Bahia. Negro, filho de uma mulher escravizada e um padre. Formou-se engenheiro em 1877 e seguiu essa profissão durante toda a sua vida, tendo dois períodos notáveis na sua trajetória profissional: em 1886 começa a atuar no serviço público paulista, onde permanece até 1903, quando se demite enredado em disputas políticas referentes ao plano de saneamento de Santos. Theodoro Sampaio sempre ocupou vários cargos simultaneamente na administração paulista, sendo um deles o posto de Diretor e Engenheiro Chefe do Serviço Sanitário do Estado, participando da fundaçáo da Escola Politécnica de São Paulo. A partir de 1904, retornou à Bahia trabalhando na implementaçáo do plano de saneamento de Salvador, e atuando mais intensamente na vida política institucional, sendo eleito deputado federal em 1927.

${ }^{3}$ Ofício de 4 de outubro de 1892 dirigido ao Secretário; Ofício de 8 de março de 1893 dirigido ao Secretário; Ofício de 6 de junho de 1893 dirigido ao Secretário. Acervo APESP. Fundo da Secretaria de Negócios do Interior. Localização: C05204.
} 
relatório e das fichas que o compóem, pelo Arquivo Público do Estado de Sáo Paulo, é acompanhada por textos de especialistas que analisam os aspectos mais importantes desse documento em relação à atuação e aos discursos promovidos pelo poder público e seus agentes. Neste artigo, nos centramos em uma discussão específica destacada pelo Relatório: as aglomeraçōes urbanas em moradias coletivas. Fazemos isso destrinchando aspectos relativos aos agentes investidores que lucravam diretamente com esse tipo de exploração do mercado de aluguéis. Portanto, o foco não é a atuação dos agentes públicos e das dinâmicas da legislação sanitária, uma perspectiva amplamente trabalhada por uma vasta produção, como nas pesquisas de Eudes Campos (1997), Raquel Rolnik (1997) e Candido Malta Campos (2002).

Abordaremos, entáo, o enfoque do trabalho da Comissáo em entender as dinâmicas de aglomeração em moradias como um fator de risco à saúde pública nas cidades, especialmente quando relacionadas a outras questôes infraestruturais. A centralidade da observação sobre as moradias coletivas empobrecidas fez com que a Comissão desvelasse as dinâmicas de reproduçáa do capital no fazer urbano em um momento de explosáo demográfica, dando relevo a como a especulaçáo imobiliária e a exploração do mercado de aluguel para os mais pobres eram parte fundamental do problema sanitário vivido em São Paulo. Desdobramos os elementos que compóem esse quadro, identificando os movimentos que trazem esses investidores e os habitantes de suas propriedades à capital paulista no final do século XIX. Para isso, destacaremos alguns aspectos do Relatório que embasam essa discussão. Na sequência abordaremos, a partir dos cruzamentos com outras fontes, como pedidos de construção e reformas de edifícios e registros de transaçôes fundiárias, a atuação de um desses investidores, Carlo Gilardi, o principal proprietário de cortiços da Santa Ifigênia. Por fim, apontaremos como esse quadro é uma expressão da colonialidade em São Paulo, especialmente a partir das suas dinâmicas populacionais relacionadas ao fim do escravismo e do tráfico da população negra africana e aos distintos tipos de imigraçáo dentro de um contexto global - entendendo colonialidade como as relações de poder globalmente estabelecidas pelas implicaçôes sociais, econômicas e culturais de longa duração do colonialismo como empresa da modernidade (QUIJANO, 1992).

\section{Impactos das moradias coletivas e adensamento de ocupação urbana na epidemia}

Santa Ifigênia, o primeiro bairro em direção a oeste desde a centralidade histórica de Sáo Paulo, abrigava, no final do século XIX, sobrados de famílias da elite paulista, cortiços, casas em série alinhadas no lote, oficinas e comércios de diversos portes, com destaque para pensôes, hospedarias e hotéis. A ocupação da região e sua urbanização tem relação, desde o período colonial, com duas irmandades negras atuantes na capital, uma em devoção à 
“ONDE AS FORÇAS VIVAS DO TRABALHO SE AJUNTAM EM DESMEDIDA": DINÂMICAS DA REPRODUÇÃO DO CAPITAL EM Sáo Paulo durante a ePidemia de FEbre amarela

Nossa Senhora do Rosário dos Homens Pretos e outra a São Elesbão e Santa Ifigênia da Etiópia, que empresta o nome ao bairro. A primeira capela construída na região, justamente por essas irmandades, data de 1721, e sua atuação permanece até hoje com a Igreja do Rosário, transferida para o principal largo da vizinhança em 1903 (SANTOS, 2019, p. 399). As dinâmicas em torno das igrejas mantiveram uma comunidade negra tanto residindo como circulando pelo bairro, assim como a proximidade com a centralidade e estaçóes de trem fez com que a regiâo se tornasse também abrigo para imigrantes europeus recém-chegados, inicialmente nas hospedagens e posteriormente na oferta crescente de moradias coletivas e quartinhos confinados nos interiores dos lotes.

A Comissão visitou e inspecionou 60 dessas construções no bairro, classificadas em: cortiços, definidos como habitaçôes acessadas através de um corredor que leva ao interior da quadra; casinhas, definidas como prédios independentes com entrada pela via pública; hotel-cortiço, usados especialmente por operários solteiros que dividiam vagas em quartos; e prédios de sobrados, definidos como construções adaptadas e subdivididas. Há ainda dois tipos apontados pela Comissáo como submoradias, com condiçôes sanitárias ainda mais preocupantes: as vendas com aposentos alugados nos fundos dos comércios e os cortiços improvisados, de tábuas de zinco, nos fundos de depósitos comerciais de madeira e materiais de construção, ou nos canteiros de obras, estábulos ou cocheiras (RODRIGUES, 2010, p. 82). Na ficha de cada unidade inspecionada, são relacionados os proprietários e também os moradores e suas respectivas nacionalidades, mostrando uma prevalência de famílias imigrantes e brasileiros solteiros entre os 1.320 residentes arrolados. Esse total, que já expressava uma superlotação em várias unidades, desrespeitando a legislação vigente, era tido pela Comissão como subestimado, pois, conhecedores das normas, vários entrevistados omitiam moradores que não estavam presentes no ato da inspeção. No Relatório, os autores reiteram que seriam necessárias visitas noturnas não agendadas para poder auferir a real ocupação de cada unidade.

Por longo período, o Relatório foi lido centralmente como um documento que refletia as políticas higienistas, que simplesmente promoviam a expulsão da população pobre do centro de São Paulo e culpavam seus hábitos pela proliferação de doenças. Apesar de parte de sua abordagem se deter, de fato, na recriminação moral dos hábitos de higiene observados em algumas unidades, a leitura da Comissão sobre as causas da insalubridade e das aglomeraçôes nessas unidades habitacionais relaciona-as primordialmente com açóes ineficientes do Estado e com a ganância dos proprietários. Parte expressiva do Relatório é dedicada a caracterizar as condiçôes topográficas do bairro, sobretudo a destacar a relação entre a antiga bacia palustre existente na região e as condiçốes sanitárias identificadas pela Comissão. Nesse caso, argumentava a Comissão, a maior disposição de encharcamento do solo foi mesmo prejudicada pela açáo do poder público, que em período próximo dessa epidemia regularizou o calçamento e piorou as condiçôes de absorção de água do solo; também pela imperícia 
na construção da rede de esgoto, do qual o bairro já era provido, mas que foi feito em nível acima da pior área de depressão da bacia palustre.

A preocupação com esse ponto devia-se a uma concentração das unidades examinadas, focos da epidemia, justamente nessa área: a rua dos Gusmóes, eixo maior da depressão, que abrigava quinze unidades; a rua General Osório, onze; a rua Santa Ifigênia, dezesseis; a rua Victoria, quatro; a avenida Duque de Caxias, a rua dos Andradas e a Triumpho, cada uma com duas unidades. Fora da bacia estava a rua Tymbiras com três unidades, a Guayanases com duas e as ruas Aurora e Conselheiro Nébias, com uma cada. Do total de unidades inspecionadas, 43 unidades estão dentro da área da bacia palustre, nas piores condiçôes sanitárias.

Figura 1: Recorte do mapa georeferenciando as unidades vistoriadas, identificadas por pin vermelho, sobre a Planta Cadastral da Cidade de São Paulo - Sta. Ephigenia (1892)

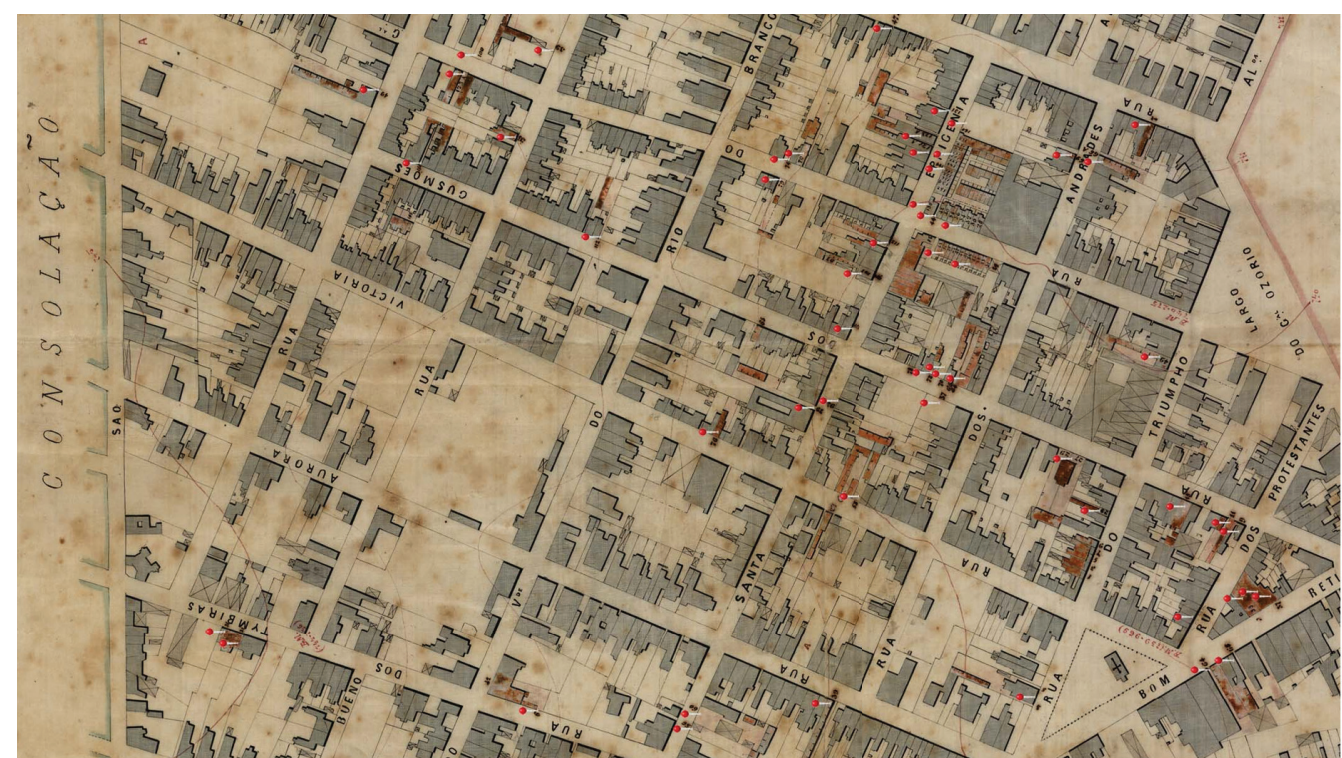

Acervo: Arquivo Público do Estado de São Paulo. Autor: Grupo HIMACO

A ineficiência do Estado em gerenciar a explosão demográfica é outro fator expresso no Relatório, apontando que as residências inspecionadas eram majoritariamente ocupadas por famílias imigrantes, compondo o grupo do principal acréscimo populacional vivido pela capital naquelas décadas. A elevada demanda por moradia com uma oferta que não comportava essa população, aliada às condiçóes desses imigrantes, sem conhecimento da língua, sem conhecimento da dinâmica da cidade, permitiu uma alta exploração no mercado de aluguéis. Especificamente no caso desses cortiços, é notável uma elevada presença de famílias provenientes do norte da Europa, com mais dificuldade de adaptação pela língua, que pagavam proporcionalmente muito mais caro para viver em condiçóes insalubres para, ao menos, terem a vantagem da localização, mitigando as dificuldades inerentes à sua con- 
“ONDE AS FORÇAS VIVAS DO TRABALHO SE AJUNTAM EM DESMEDIDA": DINÂMICAS DA REPRODUÇÁO DO CAPITAL EM Sáo Paulo durante a ePIDEMIA de FEBre amarela

dição. A relação direta entre o aumento populacional e a valorização do solo urbano, assim como da especulaçáo no mercado de aluguéis, é discutida no Relatório no sentido de indicar que o Estado deve atuar na expansão urbana, com especial atenção para o adensamento de ocupação do solo já urbanizado. Como prescrição, Sampaio defende a construção de casas operárias saneadas, fora do que era então o perímetro urbano, o que permitiria ao poder público driblar a especulação com os terrenos do centro, ao mesmo tempo em que orientava as bases da expansão urbana.

A Comissão apontava que um dos problemas para a erradicação desse tipo de moradia era seu alto nível de rendimento, já que permitiam, pela conjuntura e por suas características, uma intensa exploração dos proprietários no valor de aluguel pago por metro cúbico: quanto menor a metragem, mais elevado o valor (RIBEIRO, 2010, p. 58). Enquanto os principais agentes do mercado de terras urbanas e de loteamentos eram grandes investidores, tanto da elite tradicional paulista com herança aristocrática quanto de agentes relacionados ao mercado internacional (BRITO, 2000; CAMPOS, 2002), o mercado de aluguéis e de repartição de lotes era dominado por imigrantes ou brasileiros de primeira geração de setores médios (GENNARI, 2005; SCHNECK, 2010; FERREIRA, 2017; BORIN, 2020). Assim, se quem mais sofria nas condiçôes insalubres dos cortiços da Santa Ifigênia eram imigrantes brancos europeus, os maiores exploradores diretos dessa forma de reprodução de capital também o eram. Esses setores representavam duas faces da reverberação, nas antigas colônias, da imigração massiva europeia no processo de consolidação do capitalismo. A espoliação da terra, parte fundamental desse processo na Europa, atingia os setores mais pobres da população, que, obrigados a migrar para as cidades enfrentavam um cotidiano de miséria, formando as temidas multidôes urbanas (BRESCIANI, 1982); os setores médios também sofreram com o mesmo processo, no que concernia às possibilidades de manter um nível de vida semelhante para o conjunto de sua prole. Se, por um lado, a imigração europeia massiva serviu para desafogar as tensões sociais, levando massas de trabalhadores despossuídos ao outro lado do Atlântico, também possibilitou que imigrantes com algum pecúlio encontrassem possibilidades de investimentos possíveis longe do cenário concentracional de propriedade de terras na Europa naquele momento (ARRIGHI, 1994). Enquanto as famílias europeias evitavam a possibilidade de despromoção social não fracionando a propriedade entre a prole, também garantiam muitas vezes um retorno do investimento nos filhos não primogênitos que imigravam, investiam, e por vezes retornavam com os lucros da empreitada.

O Relatório buscou preponderantemente disputar a alocação de recursos para a reprodução de capital no fazer urbano no interior das elites. Defendia um direcionamento de investimentos e intervençôes que controlasse a questão da insalubridade, usando como mote o argumento de que esse problema impactaria a rentabilidade do negócio urbano de diversas outras formas. A Comissão identifica entáo a prática de um setor dos investidores, dos setores médios, como especialmente nefasto em promover condiçôes insalubres e centra na 
regulação da sua atividade uma medida aparentemente facilmente aplicável para modificar esse cenário. Para isso, Sampaio projeta uma imagem de unidade abstrata de todos os habitantes da cidade, tratando das prescriçóes sanitárias como se todos, independentemente da posição social, fossem igualmente beneficiados por essas políticas, operação ideológica importante nas disputas intraclasse das elites para fazer valer seus interesses nessa disputa de como rentabilizar a exploração do fazer da cidade.

A dissonância da Comissão em relação aos investidores do mercado de aluguéis é expressa em vários pontos elencados como preocupaçóes centrais no Relatório para corroborar com a imagem de que, além da especulação para aferir altos lucros, esses investidores desrespeitavam as normas e a civilidade, sendo uma grande ameaça aos projetos de melhoramentos urbanos. $\mathrm{O}$ excessivo adensamento e repartiçáo interna dos lotes, promovidos por esses agentes, são apontados no Relatório como fatores que intensificavam a dificuldade de escoamento das águas pelas condiçôes topográficas. Uma das práticas mais condenadas pela Comissão foi a criação de animais: em um cortiço onde se registraram três casos de febre amarela, funcionava uma oficina de ferreiro na frente e, no fundo, havia um galinheiro para o qual também foi prescrita a demolição ${ }^{4}$-; na rua General Osório também se alugava um cômodo que ficava em cima do galinheiro, igualmente condenado pela Comissão; ${ }^{5}$ a francesa Madame Olivier mantinha na rua Santa Ifigênia, junto à venda, uma pensão, e, na área dos fundos, também mantinha um galinheiro, cuja demolição foi ordenada; ${ }^{6}$ na ficha 49, é descrito um cortiço de propriedade de Carlo Gilardi, o maior proprietário de cortiços do bairro, que além de não fornecer a água encanada e usar iluminação por querosene, apesar de o bairro já ser provido de encanamento e luz elétrica, ainda possuía um galinheiro ao lado da latrina na área livre, que a comissão manda demolir. ${ }^{7}$ A criação de animais é registrada com preocupação no Código Sanitário, publicado no ano posterior ao Relatório e produto deste, em que são determinadas a proibição da criação de porcos dentro do perímetro urbano, e quanto à criação de outros tipos de animais, não está permitida a "aglomeraçáo excessiva" mesmo quando de "aves domésticas". 8

As propriedades de Carlo Gilardi, principal proprietário de cortiços da Santa Ifigênia, estavam concentradas nas áreas de maior depressão da bacia palustre, nas ruas dos Gusmóes e General Osório. Gilardi é um caso exemplar do tipo de investidor criticado por Sampaio, mas ele estava longe de ser uma exceçáo nesse mercado, sendo mesmo bastante representativo dos investidores que dominavam o mercado de aluguéis nos bairros centrais naquele momento. A mesma lógica de reprodução de capital aplicada por Gilardi pôde ser observada

\footnotetext{
${ }^{4}$ Ficha no 24. CORDEIRO, op. cit., p. 140.

${ }^{5}$ Ficha $\mathrm{n}^{\circ}$ 13. Ibidem, p. 129.

${ }^{6}$ Ficha ${ }^{\circ} 42$. Ibidem, p. 158.

${ }^{7}$ Ficha $\mathrm{n}^{\circ} 49$. Ibidem, p. 165.

${ }^{8}$ SÃO PAULO (1894), Decreto n. 233 de 2 de março de 1894. Estabelece o Código Sanitário do Estado de São Paulo.
} 
“ONDE AS FORÇAS VIVAS DO TRABALHO SE AJUNTAM EM DESMEDIDA": DINÂMICAS DA REPRODUÇÃO DO CAPITAL EM Sáo Paulo durante a ePidemia de FEbre amarela

por agentes com características semelhantes no trabalho de Luciana Além Gennari (2005), acompanhando os investimentos da família Valente na Mooca, assim como no de Monique Borin (2020), sobre a atuação de Possidônio das Neves e família na Liberdade. Se esse tipo de investimento não é tão visível quanto os de grandes loteamentos, o impacto que tiveram nas modificaçóes urbanas vividas por Sáo Paulo naquele momento foi expressivo. Uma observação detalhada da ocupação dos lotes e dos usos das unidades habitacionais permitiu aos membros da Comissão entender as implicações da ação desse tipo de investidor, possibilitando acessar a relação entre esse tipo de reprodução de capital com a criação de condições para propagação de epidemias. Carlo Gilardi é um agente destacado no Relatório, em que são identificadas mais de 20 propriedades suas com características de moradias coletivas investigadas pela Comissão. Entre as 288 pessoas, ao menos, que viviam em imóveis insalubres e superlotados de sua propriedade, estavam italianos, brasileiros, espanhóis, alemães, poloneses (referidos nas fichas como “polaco”), portugueses e dinamarqueses.

Tabela 1: Tabulação das fichas que analisam propriedades de Carlo Gilardi no Relatório dos Cortiços

\begin{tabular}{|c|c|c|c|}
\hline Ficha $^{\circ}$ & Tipo de construçáo & Logradouro & População estimada \\
\hline 3 & 5 casinhas & Rua General Osório, $n^{\circ} 28-36$ & 36 pessoas \\
\hline 4 & 3 casinhas & Rua General Osório, $n^{\circ} 38-42$ & 16 pessoas \\
\hline 5 & 8 casinhas & Rua General Osório, $n^{\circ} 31-45$ & 44 pessoas \\
\hline 6 & 1 cortiço & Rua General Osório, $n^{\circ} 44$ & 41 pessoas \\
\hline 7 & 5 casinhas & Rua General Osório, $n^{\circ} 47-55$ & 25 pessoas \\
\hline 23 & 1 cortiço & Rua dos Gusmóes, $n^{\circ} 70$ & Interditado \\
\hline 48 & 6 casinhas & Rua Santa Ifigênia, $n^{\circ} 130-142$ & 42 pessoas \\
\hline 49 & 1 cortiço & Rua Santa Ifigênia, $n^{\circ} 144$ & 57 pessoas \\
\hline 50 & 7 casinhas & Rua Santa Ifigênia, $n^{\circ} 146-158$ & 27 pessoas \\
\hline
\end{tabular}

Fonte: Fichas do Relatório da Commissão de exame e inspecção das habitaçôes operarias e cortiços no Districto de Sta. Ephigenia - 1893. Acervo do Arquivo Público do Estado de Sáo Paulo. Elaborado pela autora (2020).

O pedido mais antigo de Gilardi presente na Série Obras Particulares - principal conjunto documental para acompanhar as açóes desse tipo de investidor no mercado de aluguéis - é de 1888, em que ele pede alinhamento para "edificar umas casas" na rua Santa Ifigênia $n^{\circ} 40$, para o qual não apresenta planta pois ainda não estava estabelecida essa obrigatoriedade. ${ }^{10}$ Um ano antes da inspeção, em 1892, Gilardi submete novo pedido através do construtor Francisco Garcia Franco, agora para a rua General Osório, esquina com

\footnotetext{
${ }^{9}$ Estava interditado e sem moradores justamente por ser uma das propriedades em que ocorreu um óbito por febre amarela.

${ }^{10}$ Arquivo Histórico de São Paulo (1888). Ofício de Carlo Gilardi. Rua Santa Ifigênia, 40. Encadernado 30. Série Obras Particulares. Subfundo Diretoria de Obras e Viação. Fundo Prefeitura Municipal de São Paulo.
} 
a rua Santa Ifigênia, para reforma e ampliação de uma propriedade de seis cômodos. ${ }^{11} \mathrm{~A}$ reforma propunha ampliar o maior cômodo, que fica exatamente na esquina, sendo que os outros cômodos são de tamanhos diminutos, sem conexão interna, acessados diretamente pelo quintal interno ou pela rua General Osório, tratando-se provavelmente de quartinhos de aluguel. A rua General Osório concentrava investimentos importantes de Gilardi, como constatou Vanessa Lima em estudo comparativo entre suas propriedades identificadas nas fichas e pedidos de seu interesse na SOP (2014). Em 1898, esse investidor busca aprovação para algumas reformas em suas propriedades, uma delas na rua General Osório ${ }^{\circ} 55 .{ }^{12}$ Alegou que a casa que fica no alinhamento seria demolida e transformada em um portão para dar acesso ao interior do lote onde seriam construídas quatorze "casas operárias", todas no padrão de três cômodos e com latrinas individuais, em um lote todo ocupado por outras edificaçóes do mesmo proprietário:

Figura 2: Planta anexa a ofício de Carlo Gilardi (1892)

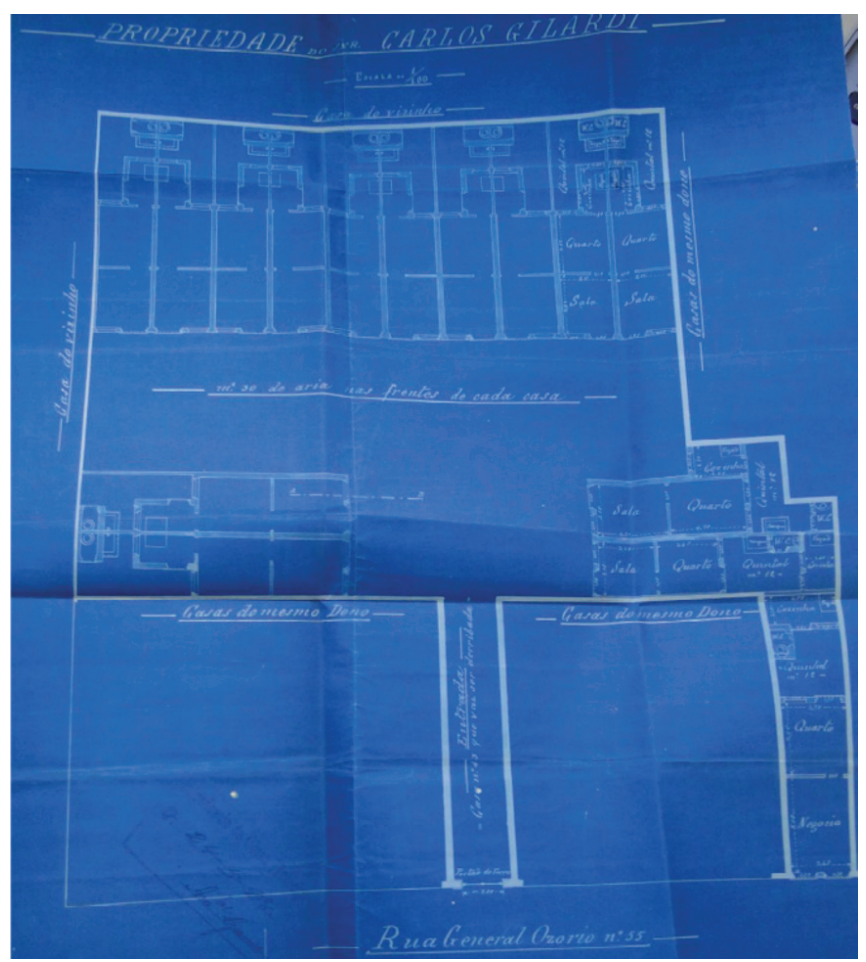

Fonte: Encadernado 6 da Série Obras Particulares. Acervo: Arquivo Histórico de São Paulo

\footnotetext{
${ }^{11}$ Arquivo Histórico de São Paulo (1892). Ofício de Carlo Gilardi. Rua General Osório, esquina com rua Santa Ifigênia. Encadernado 6. Série Obras Particulares. Subfundo Diretoria de Obras e Viação. Fundo Prefeitura Municipal de São Paulo.

${ }^{12}$ Arquivo Histórico de São Paulo (1898). Ofício de Carlo Gilardi. Rua General Osório, 55. Encadernado 200. Série Obras Particulares. Subfundo Diretoria de Obras e Viação. Fundo Prefeitura Municipal de São Paulo.
} 
“ONDE AS FORÇAS VIVAS DO TRABALHO SE AJUNTAM EM DESMEDIDA": DINÂMICAS DA REPRODUÇÃO DO CAPITAL EM Sáo Paulo durante a ePidemia de FEbre amarela

Monique Felix Borin

O pedido para a construção da vila de casas no interior do lote é aprovado. No mesmo ano, dessa vez na rua dos Gusmôes, $n^{\circ} 70$, Gilardi pede aprovação para a construção de um armazém, no mesmo endereço em que funcionava um cortiço onde morava uma das vítimas fatais da epidemia. ${ }^{13}$ Esses pedidos mostram a permanência das atividades de Gilardi de oferta desse tipo de moradia no bairro mesmo com a série de reformas prescritas para propriedades suas no Relatório. Assim, vemos que a ação da Comissão não penalizou financeiramente esses investidores em um nível que impossibilitasse a continuidade de suas atividades, ou seja, não inviabilizou a alta lucratividade desse tipo de exploração do mercado de aluguéis.

Os investimentos de Carlo Gilardi como agente urbano não foram ainda estudados sistematicamente, mas sabemos que seus rendimentos com negócios como proprietário e locador atingiram patamares vultuosos. Gilardi nasceu em Turim, hoje norte da Itália, em 1842, e lá tinha como ocupação ser "fattore" em uma propriedade agrícola nas imediaçóes da cidade, imigrando para o Uruguai com sua primeira esposa, Rosa Gilardi, onde tem seu primeiro filho, Luigi Gilardi, em $1872 .{ }^{14}$ Com o falecimento da sua esposa, casa-se novamente com Giuseppina Gilardi, com quem tem o segundo filho, Adriano Giovanni Gilardi, que nasce em São Paulo em 1890. Na década de 1880 já está em Sáo Paulo envolvido com seus negócios imobiliários, como podemos constatar pelo seu nome da lista dos proprietários que deveriam pagar o "Imposto de muros" referentes aos períodos 1881-1882 e 1882-1883 - sendo taxado por 2 metros de propriedade de "muros" na rua dos Gusmóes e 105 metros na rua General Osório - sem esquecer, nesse caso, que o imposto sobre fachadas e muros não incidia diretamente sobre o principal negócio manejado por Gilardi, o adensamento da ocupação no interior de lotes. ${ }^{15}$ No ano de 1883 , assina com outros 50 proprietários de cortiços da cidade um pedido à Assembleia Provincial para rever o aumento de impostos sobre cortiços, que haviam dobrado nesse ano, indicando, portanto, que já estava bem integrado à dinâmica dos negócios urbanos da cidade e já tinha criado uma rede com outros investidores no mercado de aluguéis. ${ }^{16}$ Gilardi por fim regressa a Turin, onde morre em 1911, enquanto seu primogênito fica encarregado dos negócios da família, porém morre poucos anos após o pai, em 1916.

No Arquivo Aguirra, há três fichas referentes aos desdobramentos das propriedades dos Gilardis pós falecimento do patriarca e de seu primogênito: uma de 1923, em que Attila

\footnotetext{
${ }^{13}$ Arquivo Histórico de Sáo Paulo (1898). Ofício de Carlo Gilardi. Rua General Osório, 70. Encadernado 201. Série Obras Particulares. Subfundo Diretoria de Obras e Viação. Fundo Prefeitura Municipal de São Paulo.

${ }^{14}$ Nas definiçóes de dicionários de italiano, fattore é uma pessoa que cuida da gestão ou administração de uma fazenda agrícola. Assim, entende-se que Carlo Gilardi antes de imigrar não era o proprietário agrícola, mas cumpria a função de feitor/senhorio, administrando e coordenando a produção e os trabalhadores de uma propriedade localizada na Strada Vaipiana, sendo provável, portanto, ter chegado com capital acumulado para fazer investimentos. O trabalho genealógico da família Gilardi foi realizado por um trineto de Carlo Gilardi, que faleceu recentemente, em 2018, na Escócia, depois de passar toda a vida em Nova York, Bruce Raymond Gilardi - que, como vários dos homens da família, também era engenheiro de formação.

${ }^{15}$ Acervo Museu Paulista (s.d.). Ficha manuscrita de Aguirra com imposto sobre muros de 1881 a 1883 referente à rua dos Gusmóes. Série Inventários. Arquivo Aguirra.

${ }^{16}$ Arquivo Histórico de São Paulo (1883). Coleção Papéis Avulsos, v. 396.
} 
“ONDE AS FORÇAS VIVAS DO TRABALHO SE AJUNTAM EM DESMEDIDA": DINÂMICAS DA REPROdUÇÃo Do CAPITAL EM Sáo Paulo durante a ePidemia de FEbre amarela

Monique Felix Borin

Gilardi, filho primogênito de Luigi, outorga o uso de propriedades a Elvira Maria Alten, mencionando propriedades em rua Santa Ifigênia n ${ }^{\circ}$ 198, 116 e 118, rua General Osório n ${ }^{\circ}$ 128, 55 e 57, 43; curioso nesse caso é que esse nome é o nome de solteira de Elvira, casada com o próprio Attila. Em 1931, consta Attila ter uma propriedade na rua Santa Ifigênia, $n^{\circ} 170$ penhorada a pedido de Domiciana Rubião Salles, na qual também são citadas propriedades na rua General Osório, já que deve se tratar de partilha e uso do interior do lote. Em 1933, Attila Gilardi e sua esposa, Elvira A. Gilardi, aparecem como vendedores de uma propriedade localizada na rua General Osório, n 55, para Primo Fuzzini e Angelina Gilardi Fuzzini, irmã de Attila, no que parece ser uma transação de repartição de herança, já que em um dos poucos trechos legíveis da ficha diz "bens deixados por Giovanni Luiz Gilardi" - não há traços desse nome dentro da genealogia disponível sobre a família. Como vemos, até pelo menos a década de 1930, a família continua em propriedade de parte considerável do patrimônio acumulado no bairro por Carlo Gilardi.

O filho mais novo do patriarca piemontês, que assume o nome de Adrian John Gilardi, quando Giuseppina, sua mãe, falece, é enviado ainda criança à Itália para estudar, ingressando posteriormente no prestigioso Instituto Politécnico de Zurique, ETH, como estudante de arquitetura, onde, porém, conclui a carreira de engenheiro civil, atuando profissionalmente na área nos EUA até sua morte, em 1974. Como vimos pelo tipo de atuação de Carlo Gilardi ainda em Turim, é provável que este já tenha chegado na América do Sul com um capital acumulado que possibilitou seus investimentos. Mas é notável que a destinação desse capital para a exploração do mercado de aluguel para a população pobre em São Paulo, sua atividade principal, já que se identificava publicamente como "proprietário", permitiu a reprodução de capital para manter esse nível de vida para sua prole. Os trânsitos transnacionais desse capital reproduzido com a exploraçáo do mercado de aluguéis para os mais pobres no solo da antiga colônia estão, no caso dos Gilardi, em todos os momentos dessa trajetória: nas dinâmicas que trazem o investidor e a maioria dos moradores das suas propriedades à capital paulista, e também no que leva o patriarca Gilardi de volta a Turim e sua prole a espalhar-se em diferentes pontos do mundo atlântico, mas atuando em atividades correlatas a que conformou seu acúmulo de capital. Entrecruzam-se processos de longa duração das disputas pela consolidação do capitalismo como sistema mundo, notadamente expressôes da colonialidade, já que a conformação desse solo colonial está estritamente ligada à expansão marítima e sua invasão de territórios, assim como o deslocamento desse contingente populacional está ligado ao tráfico e à escravização dos povos africanos e à simultânea espoliação da terra na própria Europa, compondo o quadro da imigração massiva. ${ }^{17}$ Todos esses processos estáo contidos na experiência desse agente urbano.

\footnotetext{
${ }^{17}$ Discussão detalhada sobre esse processo, e sobre o conceito de espoliação, é feita por Marx no capítulo "A assim chamada acumulação primitiva" (2013, p. 785-812).
} 
Figura 3: Ficha do Arquivo Aguirra localizando pagamento de impostos sobre muros na província de São Paulo (1881-1883)

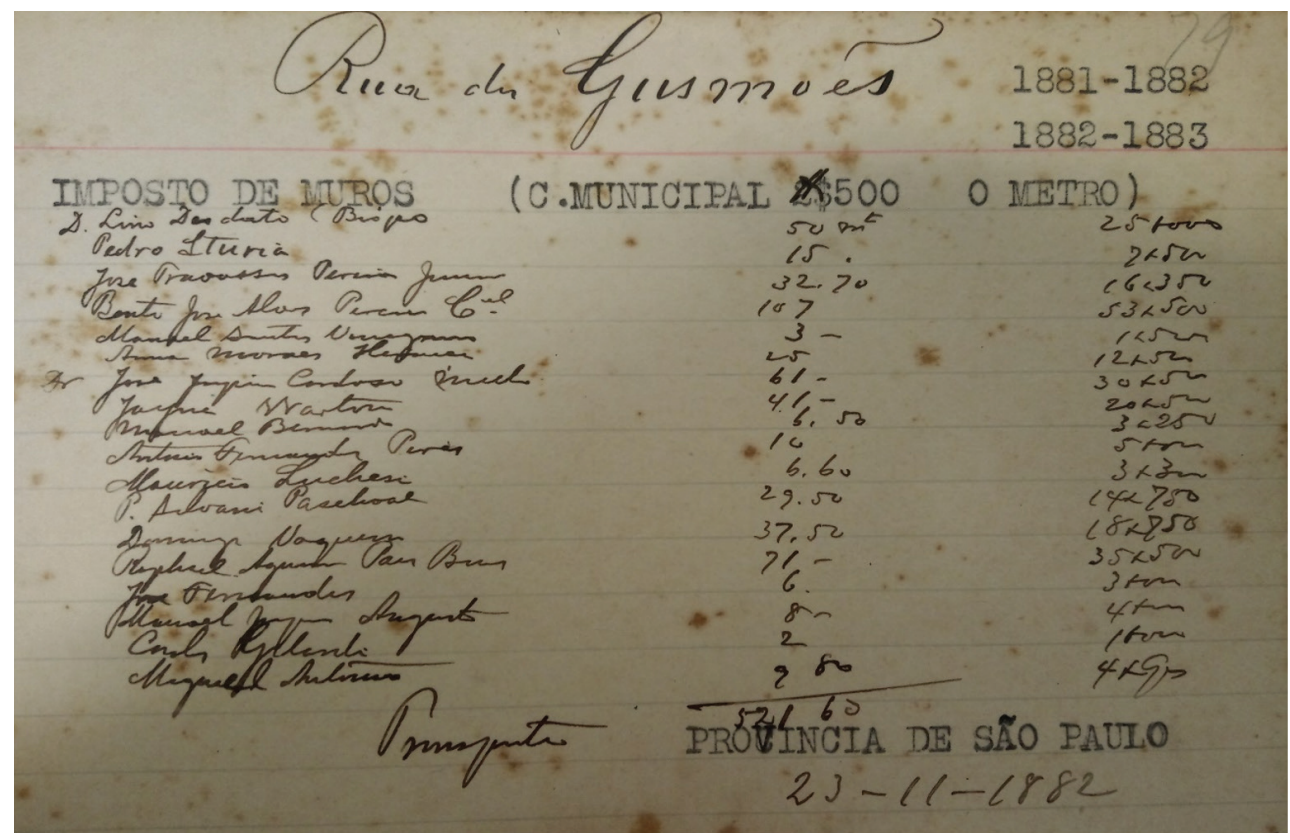

Fonte: Arquivo Aguirra. Acervo: Museu Paulista

A manutenção de pelo menos mais três proprietários no mercado de moradias coletivas após o trabalho da Comissão e as medidas solicitadas pelo relatório foi identificada por Lima (2014) em outros pedidos referentes a reformas de edificaçóes inspecionadas: os identificados na ficha 1, Rocha e Tameiráo, que posteriormente trocam uma cocheira da propriedade vistoriada para outra, localizada na alameda dos Andradas ${ }^{18}$ o proprietário identificado na ficha 10, José Savedra, aparece pedindo reforma em propriedade na mesma rua em que estava a sua propriedade vistoriada, na General Osório, num requerimento que é indeferido, pois pretendia a construção de quartos no fundo de um quintal sem área para comportar novas construções, segundo o parecer do fiscal; ${ }^{19}$ Silvani Pacal é a proprietária identificada na ficha 21 e pede a construção de um pavimento superior em uma propriedade na rua dos Gusmóes, $\mathrm{n}^{\circ} 69 .{ }^{20}$ A continuidade desse tipo de investimento no mercado imobiliário no bairro pode ser apreendida no parecer sobre a construção de duas casas na rua dos Gusmóes em 1897: “o projeto apresenta uma casa atrás da outra com entrada comum, caracterizando um cortiço. Foram solicitadas mudanças na planta e constatou-se que o projeto está de acordo com o padrão dos cortiços” (LIMA, 2014, p. 39-40).

\footnotetext{
${ }^{18}$ Ficha $n^{\circ} 1$. Relatório da Commissão de exame e inspecção das habitaçôes operarias e cortiços no Districto de Sta. Ephigenia - 1893. Edição Fac-símile: CORDEIRO. op. cit., p. 117.

${ }^{19}$ Ficha $\mathrm{n}^{\circ} 1$. Ibidem, p. 117.

${ }^{20}$ Nesse período a mudança de numeração das edificaçôes era constante. Assim, nesse caso, pode se tratar da mesma propriedade.
} 
Esse padrão estava no artigo 20 do Código de Posturas de 1886, que previa a proibição de cortiços na cidade se não fossem seguidas determinadas normativas, organizadas em sete tópicos: as construçôes no interior do lote só poderiam ser realizadas em terrenos de mais de quinze metros de largura; manutenção de cinco metros de espaços entre cada linha de cortiços; os cortiços de "uma só peça interior" deveriam ter ao menos cinco metros quadrados de área; pé direito entre quatro metros e quatro metros e meio; poróes de vinte centímetros "sendo esse espaço completo e livremente ventilado"; por fim, cortiços construídos em terrenos sujeitos à inundação deveriam ser aterrados. ${ }^{21}$ No Padrão Municipal, sessão VI, foi determinada, ainda, a proibição de construção de cortiços, casas de operários e cubículos no "perímetro do comércio", - mas não há uma delimitação desse perímetro nessa normativa nem em outras relacionadas. Após o relatório da Comissão, a Câmara passa quatro meses discutindo a proposta para a construção de casas operárias baratas e higiênicas, no entanto, o debate não continua por falta de consenso sobre o investimento da própria municipalidade na empreitada (CERASOLI, 2004, p. 167).

No ano seguinte ao Relatório, 1894, é aprovado o Código Sanitário, produto direto do Relatório, que trata dessas construçôes em dois capítulos. No terceiro, em que trata das "Habitaçôes Collectivas", classificadas sem muita precisão como habitaçôes que "domiciliam grande numero de indivíduos", é determinado que esse tipo de habitação deve ser construído "fóra da agglomeração urbana", também sem definição de qual seria esse perímetro, que banheiros são imprescindíveis e que deve haver uma latrina para cada grupo de 20 moradores. Já no capítulo cinco, que trata das "habitaçôes das classes pobres", o artigo 138 diz que a construção de novos cortiços deve ser proibida, porém tampouco define a diferença do que seria esse tipo de cortiço proibido para as habitaçóes coletivas autorizadas no capítulo três. Em 1900, o recém prefeito Antonio da Silva Prado estabelece um perímetro de proibição de "casas operárias", mas a maleabilidade dos dispositivos legais permitiu que construções desse tipo seguissem em construção mesmo dentro da área de proibiçâa. ${ }^{22}$

\footnotetext{
${ }^{21}$ Diferentemente de muitos estudos que insistem na proibição de cortiços no centro ou no perímetro urbano, os dispositivos reunidos no Código de Posturas só o proíbem no perímetro do comércio. Isso não é dizer que seria fácil ou possível construir um cortiço nas áreas mais valorizadas da cidade a partir desse período, já que as variaçôes das exigências construtivas para algumas das principais ruas do Triângulo encareciam proporcionalmente o preço das construçôes.

${ }^{22}$ A Lei n. 498, com o título "Estabelece prescripções para a construção de casas de habitação operária", tem dez artigos, no $8^{\circ}$ determina a abrangência do perímetro urbano: "rua Figueira, esquina da avenida Rangel Pestana, ruas Santa Rosa, Paula Sousa, via Tamanduatey até a linha Ingleza, por esta até as alamedas Antonio Prado, Barão de Limeira, Nothmann, rua das Palmeiras, largo de Santa Cecilia, ruas d. Viridiana, Maria Antonia, Consolação, Major Quedinho, Major Diogo, Santo Amaro, Riachuelo, praça dr. João Mendes, Largo Sete de Setembro, ruas da Glória, São Paulo, Glycerio, Hospicio, Vinte e Cinco de Março, aterrado do Carmo até o ponto de partida".
} 
“ONDE AS FORÇAS VIVAS DO TRABALHO SE AJUNTAM EM DESMEDIDA": DINÂMICAS DA REPRODUÇÃo DO CAPITAL EM Sáo Paulo durante a ePidemia de FEBre amarela

Monique Felix Borin

\section{Dimensóes da colonialidade no controle urbano}

A atuação comandada por Teodoro Sampaio tinha, então, a função de defender e buscar orientar, desde o poder público, formas de exploração dos negócios urbanos que promovessem condiçôes mais salubres, direcionando os esforços, nesse momento, ao combate de um tipo específico de investidor, representado principalmente por Gilardi. O Relatório é a expressão de uma abordagem social e política sobre a epidemia, enfocando suas prescriçóes no combate às causas que levam à propagaçáo da doença: aglomeraçáo em moradias, que, em conjunto com fatores como falta de insolaçáo e baixa ventilaçáo de cômodos, ausência de saneamento básico e acúmulo de água parada levavam ao ambiente abafado propício à propagação de diversas doenças infecciosas, entre elas a febre amarela. Desde essa perspectiva de saúde pública de controle do meio, a Comissão direcionou esforços para intervençóes de prevenção à propagação das enfermidades e não na forma específica de contágio, já que ainda não havia consenso científico naquele momento sobre esse aspecto. Tanto se o contágio acontecesse pelo contato entre pessoas, com objetos contaminados ou miasmas, como se ocorresse transmitido por um vetor, no caso da febra amarela, os mosquitos, as prescrições da Comissão eram igualmente válidas para um controle comunitário da epidemia, criando ambientes salubres que dificultavam a disseminaçáo dessa e de outras doenças infecciosas. ${ }^{23} \mathrm{~A}$ Comissão então estabelece as aglomerações em moradias como um fator de risco à propagação de doenças, defendendo que o modelo de exploraçáo de negócios urbanos desses investidores dos setores médios promovia essas aglomeraçóes, logo associando a sua forma de reprodução do capital à criação de condiçôes de moradia que propagavam doenças infecciosas.

O setor médio investidor no mercado de aluguel tem um papel na promoção das condições para a propagação dos contágios, mas não era o único setor da sociedade que compunha esse quadro, como a própria Comissão aponta quando circunscreve as responsabilidades do Estado naquele quadro epidêmico. A intervenção na propriedade privada e o choque com os interesses de alguns proprietários específicos em prol da promoção de transformaçóes urbanas que garantiriam uma organização mais eficiente para a reprodução do capital em maior vulto conformam a autoconstrução de trajetórias heroicas dos reformadores urbanos (GORELIK, 1998, p. 117). Ainda que no discurso de Sampaio a opção por fazer um enfrentamento desses médios investidores e não dos grandes loteadores ou proprietários de terras urbanas apareça

\footnotetext{
${ }^{23}$ Os debates sobre a forma de contágio se estenderam durante todo o século XIX, especialmente em torno de duas teorias. A teoria mesológica, mais conhecida como a teoria dos miasmas, estabelecia uma relação determinante entre "as características do meio físico e as condiçóes de saúde e entre os aspectos físicos e os costumes dos habitantes do lugar” (COSTA, 2003, p. 89). Essas características, como os maus odores, geravam os miasmas, responsáveis por transmitir doenças, e era a teoria em voga até as descobertas de Louis Pasteur, que constituíram a teoria microbiana. A teoria microbiana determinava que a transmissão de doenças ocorria por meio dos micróbios, microrganismos invisíveis, e não por miasmas, a busca por um consenso científico em torno dessa teoria levou algum tempo, o que fez com que as duas teorias convivessem nas práticas sanitárias por décadas (COSTA, 2003, p. 90).
} 
“ONDE AS FORÇAS VIVAS DO TRABALHO SE AJUNTAM EM DESMEDIDA": DINÂMICAS DA REPRODUÇÃO DO CAPITAL EM Sáo Paulo durante a ePidemia de FEbre amarela

como uma opção tática, pela maior possibilidade de efetivação, as suas implicaçôes e desdobramentos mostram o compromisso subjacente dessas proposiçóes. $\mathrm{O}$ compartilhamento de casas, quartos e até camas dividindo o ônus econômico do aluguel, a criação de animais em áreas urbanas para consumo e o uso simultâneo da casa como espaço de trabalho são estratégias de sobrevivência e manutenção de modos de vida comuns às populaçôes urbanas despossuídas ao longo do século XIX atingidas por reformas urbanas que muitas vezes as afastavam das suas áreas tradicionais de vizinhança. Assim, investidores como Gilardi ao mesmo tempo que lucravam vultuosamente com a exploração dessa parte da população, também permitiam condiçôes para que ela se mantivesse residindo próxima das suas redes de vizinhança e com vantagens de localização (MARINS, 2011; BORIN, 2014).

As prescrições da Comissão são debatidas politicamente, mas sempre respaldadas em aspectos definidos como técnicos. $\mathrm{O}$ combate às diversas epidemias que assolaram o mundo no curso do século XIX faz parte do longo processo de construção da autoridade suprema da técnica como operador neutro nas reformas urbanas (CHOAY, 2010; BRESCIANI, 1982). Nesse caso, como em tantos outros, percebemos como esses agentes, a partir do seu lugar de formulação, produziram uma técnica que era necessariamente segregacionista nos seus fundamentos, fazendo com que as opçôes técnicas adotadas fossem as que inevitavelmente seriam mais benéficas para a classe dos formuladores destas, mesmo que inconscientemente que, no entanto, entrava em choque ao tentar se realizar pois se deparava com a condição da disputa política cotidiana que é o fazer da cidade (BRESCIANI, 2018; 2015; BOURDIEU, 1983, p. 97-98). Havia, assim, também um sentido na formulação da imagem sobre o bairro da Santa Ifigênia promovido pelo Relatório. A imagem de um bairro dominado por cortiços e outros tipos de habitação insalubre cumpria a função de garantir uma intervenção do poder público em regular o que já era entáo visto como um centro de preocupaçáo para as elites, a partir dos diagnósticos urbanos realizados durante o século XIX: as aglomeraçôes de pobres em determinados sítios urbanos que os permitiam estratégias de sobrevivência sem se enquadrar ao mercado de trabalho regular, aos engessamentos dos seus modos de vida (TOPALOV, 1996, p. 33-35).

Teodoro Sampaio, como um engenheiro reformador, negro, por meio de sua atuação no poder público cujas políticas impactaram essa populaçáo pobre, majoritariamente europeia, branca, nos permite acercar de uma encruzilhada dos conflitos sociais do século XIX e princípio do século XX, bastante sensível na expressão das contradiçôes gestadas pela colonialidade e pelo escravismo. Portanto, não expressam uma peculiaridade da condição da formação social das colônias, mas sim o entrelaçamento e o enraizamento que as relaçóes estabelecidas pelo colonialismo deixaram nas relações em todos os territórios que o conformaram, seja em qual lado do oceano estejam, borrando as fronteiras por ele mesmo criadas. A imigraçáo massiva foi também um recurso para controlar as multidóes urbanas na Europa, seja em direção à América do Norte ou do Sul. Esse contingente populacional concentrado 
“ONDE AS FORÇAS VIVAS DO TRABALHO SE AJUNTAM EM DESMEDIDA": DINÂMICAS DA REPRODUÇÃO DO CAPITAL EM Sáo Paulo durante a ePidemia de FEbre amarela

nas cidades foi gerado nas disputas pela consolidação da forma capitalista de trabalho através dos cercamentos, do combate às atividades das corporaçôes e também de outros tipos de trabalho intermitentes (MARX, 2013, p. 785-812; THOMPSON, 1998; 2010). Ao mesmo tempo, as levas de imigrantes europeus brancos trazidas aos territórios das antigas colônias compunham os projetos de branqueamento da população, em uma intrincada estratégia que parecia apenas prever a simples substituiçáo de negros escravizados por trabalhadores livres brancos, mas que também serviu como uma forma de construir no trabalhador não branco a imagem da despromoção social, gerando assim outras possibilidades de ampliação da reprodução do capital na exploração da mão de obra (AZEVEDO, 2004; GÓES, 2011; WALDMAN, 2013; LOPES, 2015).

Aqui, portanto, entrecruzam-se a constituição de um mercado formal assalariado no mundo capitalista e as bases deixadas pela colonialidade, uma condição fraturada dentro das populaçôes trabalhadoras e pobres no mundo ocidental para se constituírem como classe. Uma faceta dramática dessa questão são as forças militares racializadas que combateram processos de independência ou insurreiçôes populares, nos territórios coloniais ou mesmo no solo europeu, mostrando o quanto a construçáo dessa doutrina de controle urbano tem intersecçóes profundas com a própria constituição do colonialismo. ${ }^{24}$ Para dimensionar com mais propriedade essa questão, seria importante entender que, diferentemente do que costumamos manejar como contexto histórico da imigração europeia massiva para países americanos, a relação entre os africanos traficados, os indígenas escravizados e a população pobre europeia não se deu somente quando estes se encontram no solo colonial, mas está mesmo na própria imbricação da formação dos estados-nação europeus com o colonialismo e escravismo:

[...] as economias dentro das quais o capitalismo começa a se desenvolver não eram economias "nacionais", mas antes economias políticas delimitadas por estados "absolutistas". Ainda que não se possa dizer que essa característica estrutural tenha determinado as relaçóes sociais capitalistas, todavia ela as moldou de maneiras profundas, e as ideologias associadas às previas relaçôes feudais foram preservadas e transformadas na nova situação. As transformaçôes das ideologias "racistas" dirigidas contra as "classes inferiores" são um caso em questão. [...] Fraçôes da burguesia e do proletariado emergente foram retiradas tanto de outras terras quanto de partes de estados particulares, e como sabemos, a força de trabalho escravo seria trazida de "mundos inteiramente diferentes". Robinson sustenta que a importância do trabalho "imigrante" nas economias capitalistas em desenvolvimento permaneceu amplamente não analisada, em parte por causa do uso acrítico da "nação" como uma unidade de análise. No entanto, a naçáo como tal ainda não existia e as ideologias da nação que almejavam unir os grupos e classes díspares náo foram elaboradas até que o modo de produção capitalista já tivesse começado a produzir. A escravização de africanos e asiáticos, o uso de asiáticos como mão de obra contratada e as formas particulares

${ }^{24}$ Ver em Madariaga (2002) e Kraay (2012). 
“ONDE AS FORÇAS VIVAS DO TRABALHO SE AJUNTAM EM DESMEDIDA": DINÂMICAS DA REPRODUÇÃO DO CAPITAL EM Sáo Paulo durante a ePidemia de FEbre amarela

Monique Felix Borin

de ideologias racistas que foram construídas para racionalizar tais atividades não eram peculiares ao capitalismo, mas pareciam ter suas "raízes" firmemente incrustradas em formas anteriores da organização do trabalho nas sociedades europeias (LAWRENCE, 1982, p. 58-59). ${ }^{25}$

Nesse circuito, os estados nacionais são criados, legitimados e fortalecidos às custas da exploração colonial e do escravismo, que por sua vez permitem o acúmulo de capital que possibilitou a revolução industrial e o avanço do processo de submissão da população pobre europeia à condição de trabalhador regular na indústria. Esse processo já há muito conhecido e tomado como contexto histórico para numerosas narrativas de processos que aconteceram na Europa, também é diretamente relacionado ao desterramento e imigração massiva, e, com isso, ajuda a explicitar a condição mundialmente fraturada do fazer da classe trabalhadora, mais acintosa no território colonial. Esse tipo de agente urbano que tratamos especialmente aqui, imigrante de setores médios investindo no mercado de aluguéis, é também parte desse processo. As dinâmicas do fluxo imigratório favoreceram, desde cedo, a vinda de investidores, seja pela elevada demanda criada, seja pelas facilidades na mobilidade de investimentos. Ainda que esse tipo de imigrante, que já chegava ao seu destino com pecúlio suficiente para investir, fossem minoritários durante a imigração europeia massiva para o Brasil, ela marcou um determinado imaginário público sobre o processo e seus desdobramentos. Se Gilardi reforça a imagem do imigrante europeu que prospera, os moradores dos cortiços e casinhas do Relatório nos permitem também acessar outra faceta da imigração, muito mais dramática e menos emblemática - e, sem dúvida, uma condição muito mais comum entre os imigrantes despossuídos que chegam à cidade até o começo do século XX.

No ano do relatório, 1893, a população de São Paulo contava com um percentual de $55 \%$ de habitantes imigrantes, dado geralmente manejado em narrativas explicativas das transformaçóes urbanas da cidade. Essa historiografia destaca a acentuada preponderância de população imigrante no bairro final do século XIX, visto sua proximidade com as princi-

\footnotetext{
${ }^{25}$ Tradução da autora. No original: "[...] that the economies within which capitalism begins to develop were not 'national' economies but rather political economies bounded by 'absolutist' states. While this structural feature cannot be said to have determined capitalist social relations, it did nevertheless shape them in profound ways, and ideologies associated with earlier feudal relations were preserved and transformed in the new situation. The transformations of 'racist' ideologies directed against the 'lower orders' are a case in point. [...] Sections of the bourgeoisie and the emerging proletariat were drawn as much from other lands as from parts of the particular state, and as we know the slave labour force would be brought from 'entirely different worlds'. Robinson maintains though that the significance of 'immigrant' labour in the developing capitalist economies has remained largely unanalysed, partly because of the uncritical use of the 'nation' as a unit of analysis. However, the nation as such did not yet exist and the ideologies of the nation which were to attempt to bind the disparate groups and classes together, were not elaborated until after the capitalist mode of production had already begun to produce. The enslaving of Africans and Asians, the use of Asians as indentured labour, and the particular forms of racist ideologies that were constructed to rationalize such activities, were not peculiar to capitalism but rather would appear to have their 'roots' firmly embedded in earlier forms of organization of labour within European societies".
} 
pais estaçóes de trem na cidade, uma presença difundida de pensôes e hotéis que abrigavam inicialmente parte dessa população. Se essas condiçóes tornaram a regiáo atrativa para esse tipo de investimento, também a tornaram um fator de preocupaçáo para as autoridades públicas, tornando indissociáveis a preocupação sanitária e a preocupação do controle social das populaçôes pobres. Todo esse largo e complexo processo faz parte das condiçóes que gestaram esse foco epidêmico da febre amarela no bairro da Santa Ifigênia, mostrando que reduzir suas causas a uma questão pontual de hábitos higiênicos ou tipos de investimento isoladamente não dão conta de dimensionar historicamente as reverberaçóes que comportam essa epidemia. Desdobrando os conflitos a partir do combate da epidemia de febre amarela em São Paulo podemos ver como essas aglomeraçóes urbanas não são um revés de uma política de incentivo à imigração mal gerenciada. Se há uma discussão consolidada na historiografia de como a subvenção à imigraçáo massiva foi uma ação deliberada para produzir um excesso de máo de obra, que por sua vez foi fundamental para garantir a expressiva lucratividade do capital cafeeiro (PINTO, 1994; SANTOS, 2006), também cabe discutir como o direcionamento de parte desse contingente populacional para as cidades permitiu vultosos lucros na exploração do negócio urbano, especialmente no mercado de aluguéis.

A epidemia de febre amarela na Santa Ifigênia não foi o episódio epidêmico mais letal vivenciado pela cidade ao longo do século XIX, no entanto, vemos que comporta questóes fundamentais que atravessam todo o processo de transformação urbana de São Paulo naquele momento. $\mathrm{O}$ entrelaçamento dessas distintas dimensóes nos mostram como as aglomeraçôes urbanas, como condição e como discurso, são expressōes de processos amplos e globais, com implicações históricas duradouras. A articulação entre a reprodução do capital no fazer urbano e as formas de controle social dos despossuídos urbanos não é um fenômeno isolado deste estudo de caso, ainda que seja importante dar relevo às diferentes estratégias operadas em condições de expressão distintas da colonialidade. Para explorar essa nebulosa do combate às epidemias, é necessário, ainda que o olhar esteja centrado em uma questáo mais específica, apreender a dimensão sumamente política da construção do ideário da neutralidade científica e da técnica nos embates pela consolidação do capitalismo como sistema mundo.

\section{Fontes primárias}

Arquivo Público do Estado de São Paulo

Relatório da Commissão de exame e inspecção das habitaçôes operarias e cortiços no Districto de Sta. Ephigenia - 1893. Edição Fac-simile: CORDEIRO, Simone Lucena (org.). Os cortiços de Santa Ifigênia: sanitarismo e urbanização (1893). São Paulo: Imprensa Oficial; Arquivo Público do Estado de S. Paulo, 2010. 
Ofício de 4 de outubro de 1892 dirigido ao Secretário; Ofício de 8 de março de 1893 dirigido ao Secretário; Ofício de 6 de junho de 1893 dirigido ao Secretário. Acervo APESP. Fundo da Secretaria de Negócios do Interior. Localização: C05204.

SÃO PAULO (1894). Decreto n. 233 de 2 de março de 1894. Estabelece o Código Sanitário do Estado de São Paulo.

\section{Arquivo Histórico de São Paulo}

ARQUIVO Histórico de São Paulo (1888). Ofício de Carlo Gilardi. Rua Santa Ifigênia, 40. Encadernado 30. Série Obras Particulares. Subfundo Diretoria de Obras e Viação. Fundo Prefeitura Municipal de São Paulo.

ARQUIVO Histórico de São Paulo (1892). Ofício de Carlo Gilardi. Rua General Osório esquina com rua Santa Ifigênia. Encadernado 6. Série Obras Particulares. Subfundo Diretoria de Obras e Viação. Fundo Prefeitura Municipal de São Paulo.

ARQUIVO Histórico de São Paulo (1898). Ofício de Carlo Gilardi. Rua General Osório, 55. Encadernado 200. Série Obras Particulares. Subfundo Diretoria de Obras e Viação. Fundo Prefeitura Municipal de São Paulo.

ARQUIVO Histórico de São Paulo (1898). Ofício de Carlo Gilardi. Rua General Osório, 70. Encadernado 201. Série Obras Particulares. Subfundo Diretoria de Obras e Viação. Fundo Prefeitura Municipal de São Paulo.

ARQUIVO Histórico de São Paulo (1883). Coleção Papéis Avulsos, v. 396.

Museu Paulista

ACERVO Museu Paulista (S/D). Ficha manuscrita de Aguirra com imposto sobre muros de 1881 a 1883, referente à rua dos Gusmóes. Série Inventários. Arquivo Aguirra.

\section{Referências}

ANDRADE, Margarida Maria de. Bairros além Tamanduateí: o imigrante e a fábrica no Brás, Mooca e Belenzinho. Tese (Doutorado em Geografia Humana) - Faculdade de Filosofia, Letras e Ciências Humanas da Universidade de São Paulo, 1991.

ARRIGHI, Giovanni. O longo século XX: dinheiro, poder e as origens do nosso tempo. São Paulo: UNESP, 1994.

AZEVEDO, Célia Maria Marinho de. Onda negra, medo branco: o negro no imaginário das 
“ONDE AS FORÇAS VIVAS DO TRABALHO SE AJUNTAM EM DESMEDIDA": DINÂMICAS DA REPRODUÇÃO DO CAPITAL EM Sáo Paulo durante a ePidemia de FEbre amarela

elites no século XIX. São Paulo: Annablume, 2004.

BENCHIMOL, Jaime Larry. Pereira Passos: um Haussmann tropical. A renovação urbana na cidade do Rio de Janeiro no início do século XX. Rio de Janeiro: Secretaria Municipal de Cultura, Turismo e Esportes, 1992.

BENCHIMOL, Jaime Larry (coord.). Febre amarela: a doença e a vacina, uma história inacabada. Rio de Janeiro: Editora Fiocruz, 2001.

BERTOLLI FILHO, Cláudio. A gripe espanhola em São Paulo, 1918: epidemia e sociedade. São Paulo: Paz e Terra, 2003.

BORIN, Monique Félix. A Barra Funda e o fazer da cidade: experiências da urbanização em São Paulo (1890-1920). Dissertaçáo (Mestrado em História) - Faculdade de Filosofia, Letras e Ciências Humanas da Universidade de São Paulo, São Paulo, 2014.

BORIN, Monique Félix. Experiências da urbanização na Santa Ifigênia e Liberdade: (des) caminhos da modernização de São Paulo nos bairros centrais (1886-1923). Tese (Doutorado em História) - Instituto de Filosofia e Ciências Humanas da Universidade Estadual de Campinas, 2020.

BOURDIEU, Pierre. Gostos de classe e estilos de vida. In: ORTIZ, Renato (org.). Bourdieu - Sociologia. São Paulo: Ática. Coleção Grandes Cientistas Sociais, v. 39, 1983. p. 82-121.

BRESCIANI, Maria Stela Martins. Sanitarismo e configuração do espaço urbano. In: CORDEIRO, Simone Lucena (org.). Os cortiços de Santa Ifigênia: sanitarismo e urbanização (1893). 1 ed. São Paulo: Imprensa Oficial; Arquivo Público do Estado de S. Paulo, 2010. p. 15-38.

BRESCIANI, Maria Stela Martins. Da cidade e do urbano: experiências, sensibilidades, projeto. São Paulo: Alameda, 2018.

BRESCIANI, Maria Stela Martins. Interdisciplinaridade? transdisciplinaridade nos estudos urbanos. Urbana: Revista Eletrônica do Centro Interdisciplinar de Estudos da Cidade, v. 7, n. 1, p. 10-62, 2015.

BRESCIANI, Maria Stela Martins. Londres e Paris: o espetáculo da pobreza. Sáo Paulo: Brasiliense, 1982.

BRITO, Mônica Silveira. A participação da iniciativa privada na produção do espaço urbano: São Paulo, 1890-1911. Dissertação (Mestrado em Geografia Humana) - Faculdade de Filosofia, Letras e Ciências Humanas da Universidade de Sáo Paulo, 2000.

CAMPOS, Cândido Malta. Os rumos da cidade: urbanismo e modernização em São Paulo. Sáo Paulo: Editora Senac, 2002.

CAMPOS, Eudes. Arquitetura paulistana sob o Império: aspectos da formação da cultura burguesa em São Paulo. Tese (Doutorado em Arquitetura e Urbanismo) - Faculdade de Arquitetura e Urbanismo da Universidade de São Paulo, 1997. 
“ONDE AS FORÇAS VIVAS DO TRABALHO SE AJUNTAM EM DESMEDIDA": DINÂMICAS DA REPRODUÇÃO DO CAPITAL EM Sáo Paulo durante a ePidemia de FEbre amarela

Monique Felix Borin

CERASOLI, Josianne Francia. Modernização no plural: obras públicas, tensóes sociais e cidadania em Sáo Paulo na passagem do século XIX para o XX. Tese (Doutorado em História) - Instituto de Filosofia e Ciências Humanas da Universidade Estadual de Campinas, 2004. CHOAY, Françoise. O urbanismo, utopias e realidade, uma antologia. São Paulo: Perspectiva, 2015.

CORDEIRO, Simone Lucena (org.). Os cortiços de Santa Ifigênia: sanitarismo e urbanização (1893). 1. ed. São Paulo: Imprensa Oficial; Arquivo Público do Estado de S. Paulo, 2010.

COSTA, Luiz Augusto Maia. O ideário urbano paulista na virada do século: o engenheiro Theodoro Sampaio e as questôes territoriais e urbanas modernas. São Paulo: RIMA FAPESP, 2003.

FERREIRA, Pedro Beresin Schleder. A avenida de mil vias: conflito, contradição e ambivalência na modernização de São Paulo (1890-1920). Dissertação (Mestrado em Arquitetura e Urbanismo) - Faculdade de Arquitetura e Urbanismo, Universidade de São Paulo, 2017.

GENNARI, Luciana Além. As casas em série do Brás e da Mooca: um aspecto da constituição da cidade de São Paulo. Dissertação (Mestrado em Arquitetura e Urbanismo) - Faculdade de Arquitetura e Urbanismo da Universidade de São Paulo, São Paulo, 2005.

GÓES, Weber Lopes. O pensamento de Arthur de Gobineau no seio do caleidoscópio da ideologia do racismo. Monografia [Especialização em Ciências Sociais - Economia Mundo: Arte e Sociedade] - Fundação Santo André, Santo André, 2011.

GORELIK, Adrián. La grilla y el parque: espacio público y cultura urbana em Buenos Aires (1887-1936). Bernal: Editora de la Universidad Nacional de Quilmes, 1998.

GUERREIRO RAMOS, Alberto. Patologia social do branco brasileiro. Jornal do Comércio, jan. 1955.

HALL, Michael. A imigração na cidade de São Paulo. In: PORTA, Paula (org.). História da cidade de Sáo Paulo. v. 3: a cidade na primeira metade do século XX, 1890-1954. Rio de Janeiro: Paz e Terra, 2004. p. 121-151.

KRAAY, Hendrik. Os companheiros de Dom Obá: os zuavos baianos e outras companhias negras na Guerra do Paraguai. Afro-Ásia, Salvador, n. 46, p. 121-161, 2012.

LAWRENCE, Errol. Just plain common sense: the 'roots' of racismo. In: CENTER FOR CONTEMPORARY CULTURAL STUDIES. The Empire Strikes Back: Race and Racism in 70's Britain. Londres: Routledge, 1982. p. 45-92.

LIMA, Vanessa Alves de. Experiências da urbanização em Santa Ifigênia: habitação, sanitarismo e salubridade. Trabalho de conclusão de curso (História). UNIFESP, 2014.

LOPES, Tabita Tiede. Percursos do branqueamento: Família Prado e imigração em São Paulo. Dissertação (Mestrado em Ciências Sociais) - Escola de Filosofia, Letras e Ciências Humanas, Universidade Federal de São Paulo (UNIFESP), Guarulhos, 2015. 
“ONDE AS FORÇAS VIVAS DO TRABALHO SE AJUNTAM EM DESMEDIDA": DINÂMICAS DA REPRODUÇÃO DO CAPITAL EM Sáo Paulo durante a ePidemia de FEBre amarela

Monique Felix Borin

MADARIAGA, María Rosa de. Los moros que trajo Franco. La intervención de tropas coloniales en la guerra civil. Madrid: Martínez Roca, 2002.

MARINS, Paula César Garcez. Um lugar para as elites: os Campos Elíseos de Glette e Nothmann no imaginário urbano de Sáo Paulo. In: LANNA, Ana Lucia Duarte; PEIXOTO, Fernanda Arêas; LIRA, José Tavares Correia de; SAMPAIO, Maria Ruth Amaral de (orgs.). São Paulo, os estrangeiros e a construção das cidades, v. 1. São Paulo: Alameda, 2011. p. 209-244. MARTINS, Valter. Cidade-laboratório: Campinas e a febre amarela na aurora republicana. História, Ciências, Saúde - Manguinhos, Rio de Janeiro, v. 22, n. 2, p. 507-524, abr.-jun. 2015.

MARX, Karl. O capital: crítica da econômica política. Livro I: o processo de produção capitalista. São Paulo: Boitempo, 2013.

PINTO, Maria Inez Machado Borges. Cotidiano e sobrevivência: a vida do trabalhador pobre na cidade de São Paulo, 1890-1914. São Paulo: EDUSP, 1994.

QUIJANO, Aníbal. Colonialidad y modernidad/racionalidade. Perú Indígena, n. 29, 1992. RIBEIRO, Maria Alice Rosa. Os cortiços no distrito de Santa Ifigênia (1893). In: CORDEIRO, Simone Lucena (org.). Os cortiços de Santa Ifigênia: sanitarismo e urbanização (1893). 1. ed. São Paulo: Imprensa Oficial; Arquivo Público do Estado de S. Paulo, 2010. p. 39-78.

RODRIGUES, Jaime. Da 'chaga oculta' aos dormitórios suburbanos: notas sobre higiene e habitação operária na São Paulo de fins do século XIX. In: CORDEIRO, Simone Lucena (org.). Os cortiços de Santa Ifigênia: sanitarismo e urbanização (1893). São Paulo: Imprensa Oficial; Arquivo Público do Estado de S. Paulo, 2010. p. 79-90.

ROLNIK, Raquel. A cidade e a lei: legislação, política urbana e territórios na cidade de São Paulo. São Paulo: Nobel, 1997.

SANTOS, Fabio Alexandre dos. Domando as águas: salubridade e ocupação do espaço na cidade de São Paulo, 1875-1930. Tese (Doutorado em Economia) - Instituto de Economia da Universidade Estadual de Campinas, 2006.

SANTOS, Fabricio Forganes. As Igrejas das Irmandades dos Homens Pretos e a memória afro-brasileira no urbanismo da cidade de São Paulo. In: Anais do II Seminário Internacional Espaços Narrados: as línguas na construção dos territórios ibero-americanos, v. 1, p. 392-412. São Paulo: FAU/USP, 2019.

SCHNECK, Sheila. Formação do bairro do Bexiga em São Paulo: loteadores, proprietários, construtores, tipologias edilícias e usuários (1881-1913). Dissertação (Mestrado em Arquitetura e Urbanismo) - Universidade de São Paulo, São Paulo, 2010.

THOMPSOMN, Edward Palmer. A formação da classe operária inglesa: a árvore da liberdade. Rio de Janeiro: Paz e Terra, 2010. 
THOMPSOMN, Edward Palmer. A economia moral da multidão inglesa no século XVIII. In: THOMPSOMN, Edward Palmer. Costumes em comum. São Paulo: Companhia das Letras, 1998. p. 150-202.

TOPALOV, Christian. Da questão social aos problemas urbanos: os reformadores e a população das metrópoles em princípios do século XX. In: RIBEIRO, Luiz César Q; PECHMAN, Robert (orgs.). Cidade, povo e nação. Rio de Janeiro: Civilização Brasileira, 1996.

WALDMAN, Thaís Chang. A São Paulo dos Prados. Ponto Urbe [Online], n. 13, 2013. 